Rio de Janeiro. Ano 11. Volume 18. Número 3. Setembro a Dezembro de 2017

Periódico Quadrimestral da Pós-Graduação Stricto Sensu em Direito Processual da UERJ

Patrono: José Carlos Barbosa Moreira. ISSN 1982-7636. pp. 45-68

www.redp.uerj.br

\title{
A FIGURA DO ASSISTENTE TÉCNICO NO PROCESSO PENAL: QUESTÕES LEGISLATIVAS E DOUTRINARIAS ${ }^{1}$
}

\section{TECNICAL ASSISTANT IN CRIMINAL PROCEDURE: LEGISLATIVE AND DOCTRINAL QUESTIONS}

Chiavelli Falavigno Graduada em Direito pela Universidade Federal do Rio Grande do Sul com período de intercâmbio acadêmico na Universidade de Coimbra/Portugal (bolsista Santander). Mestre em Ciências Criminais aprovada com voto de louvor pela Pontifícia Universidade Católica do Rio Grande do Sul (bolsista CAPES). Doutoranda em Direito Penal pela Universidade de São Paulo (bolsista FAPESP) com período sanduíche em 2017 na Hamburg Universität/Alemanha (bolsista DAAD). Advogada. chiavelli.falavigno@gmail.com

Guilherme Ziliani Carnelós Bacharel em Direito (PUC/SP, 2003). Especialista em Direito Penal Econômico (Faculdade de Direito da Fundação. Getúlio Vargas, 2006). Diretor do Instituto de Defesa do Direito de Defesa (IDDD). Advogado. guilherme@rcva.adv.br

RESUMO: O presente trabalho tem como escopo analisar aspectos polêmicos referentes à prova pericial no processo penal, principalmente no que tange às diferenças existentes entre a figura do perito e a do assistente técnico. Este último se trata de inovação trazida ao Código pátrio pela Lei n. 11.690 de 2008, a qual deu origem a mais uma das tantas reformas parciais já sofridas pelo dito diploma. Visa-se também explicitar, neste trabalho, as questões atinentes às possibilidades de contraditório e ampla defesa nas provas periciais

\footnotetext{
${ }^{1}$ Artigo recebido em 03/06/2017 e aprovado em 21/11/2017.
} 
produzidas durante a investigação e no curso da ação penal. Por fim, realizar-se-á uma breve análise de legislação comparada entre Brasil, Chile e Itália. A metodologia utilizada é pesquisa bibliográfica, legislativa e jurisprudencial.

PALAVRAS-CHAVE: Prova pericial. Assistente técnico. Contraditório. Inquérito policial.

ABSTRACT: This article has the objective to analyze controversial aspects relating to expert evidence in criminal proceedings, especially about differences between the expert's figure and his assistant. The assistant is an innovation brought to the code by Law $\mathrm{n}$. 11.690 of 2008, which gave rise to one more of the many partial reforms already suffered by the diploma. The aim is also to clarify the contradictory possibilities in expert proof produced during the investigation and in the criminal proceedings. Finally, there is a brief analysis of comparative law between Brazil, Chile and Italy. The methodology used is literature, legislative and jurisprudential research.

KEYWORDS: Expert proof. Technical assistant. Contradictory. Police investigation.

SUMÁRIO: Introdução. 1. Perícia - conceito, classificações e generalidades. 2. O perito e o assistente técnico. 3. As inovações da Lei n. 11.690/2008: análise comparativa com as regras do Código de Processo Civil. 4. Perícias feitas na fase inquisitorial e a atuação defensiva. 5. Problemas no exercício do contraditório decorrentes da nomeação de assistente técnico. 6. O peso probatório do laudo particular. 7. Legislação comparada: perícia e assistente técnico no Chile e na Itália. Considerações finais. Referências bibliográficas.

\section{INTRODUÇÃO.}

O estudo dos meios de prova no processo penal brasileiro tem-se tornado a cada dia mais importante, principalmente tendo em vista a consagração doutrinaria da necessária 
prevalência do modelo acusatório sobre aquele de viés inquisitório. Assim, aumenta-se o poder das partes, que passam a ser protagonistas na busca da verdade. ${ }^{2}$

Nesse sentido, avulta a relevância da prova científica ou pericial, a qual traz aos autos a palavra de um especialista não mais no direito, mas nas demais ciências pertinentes à discussão travada no caso concreto. Atualmente, especificamente no que tange à prova pericial, as partes passaram a ter uma maior ingerência por meio da figura do assistente técnico, que foi introduzida em 2008.

Cabe salientar que o Código de Processo Penal brasileiro, confeccionado em 1941, vem sofrendo sucessivas reformas parciais, as quais buscam emprestar-lhe um caráter que se amolde não só aos mais recentes entendimentos doutrinários, mas também à Constituição Federal, promulgada mais de quarenta anos depois, em 1988. Em que pese possa se auferir a permanência na dita legislação processual de muitos dispositivos de caráter eminentemente inquisitório, os quais concedem iniciativas probatórias a magistrado supostamente imparcial, as reformas posteriores buscam, de um modo geral, amenizar ditas características, o que também se vislumbrou por meio da Lei n. 11.690, de 2008, que alterou substancialmente a disciplina da prova pericial.

Assim, importa analisar as diversas nuances da dita prova e seus aspectos polêmicos, focando-se, para tanto, nas diferenciações possíveis entre a figura do perito e a do assistente técnico, bem como nas possibilidades de concretização das garantias processuais penais do contraditório e da ampla defesa na produção dessa prova, tanto em sede de investigação como de ação penal.

\section{PERÍCIA - CONCEITO, CLASSIFICAÇÕES E GENERALIDADES.}

A perícia consiste em um exame para cuja produção são necessários "conhecimentos técnicos, científicos ou artísticos", 3 os quais o magistrado não possui. O exame pericial é composto geralmente por três partes, quais sejam: a observação - em que

\footnotetext{
${ }^{2}$ A discussão sobre o real objetivo do processo penal - se seria a busca da verdade real, que consiste na reconstrução histórica dos fatos minuciosamente como ocorreram, ou se seria a busca da verdade formal, que é aquela que pode ser obtida pelos meios processualmente permitidos - vem, há muito tempo, dividindo a doutrina pátria. Ainda que não seja este o escopo desse trabalho, o tema merece ser, neste ponto, destacado, visando à boa compreensão dos assuntos desenvolvidos nessa pesquisa.

${ }^{3}$ TORNAGHI, Hélio. Instituições de processo penal. Rio de Janeiro, Forense, 1959, vol. IV, p. 271.
} 
ocorre a percepção sensorial por parte do perito -, a avaliação - na qual o perito faz uso de seus conhecimentos especiais -, e a declaração - na qual se exerce o juízo de valor, emitindo-se conclusão sobre o fenômeno analisado.

Há, na doutrina, algumas classificações a respeito da prova pericial. A primeira delas é a que divide as perícias em extrínsecas e intrínsecas. ${ }^{4}$ A perícia extrínseca é aquela feita sobre pessoas ou coisas que servem à prova do crime, muitas vezes pelo desaparecimento do objeto principal, chamado corpo de delito. Já a perícia intrínseca se dá, por óbvio, justamente sobre o chamado corpo de delito, como o cadáver, no caso do delito de homicídio.

No que tange à atividade do perito, a doutrina a classifica como percipiendi ou deducendi. A perícia percipiendi é aquela em que o profissional se limita a descrever o que observa de forma técnica, sem emissão de juízo de valor, como ocorre no caso de verificação de poluição sonora. Já a perícia deducendi exige que o profissional interprete a ocorrência, utilizando-se de seus conhecimentos científicos para deduzir fatos além do que a percepção sensorial aponta, como no caso da determinação do curso feito com o disparo de um projétil. ${ }^{5}$

O laudo pericial é composto de quatro partes: o preâmbulo - no qual consta o nome, o local, o motivo da perícia, dentre outros -, a exposição - na qual se expõe o histórico e a narração do que foi observado -, a discussão - momento em que ocorre a análise ou a crítica dos fatos - e, por fim, a conclusão - que é quando o perito oferece a resposta aos quesitos.

No que tange especificamente à prova pericial, a principal mudança ocorrida em 2008 diz respeito ao número de peritos necessários para a conclusão do exame, que passou de dois para apenas um, conforme expressa redação do artigo 159, do Código de Processo Penal. ${ }^{6}$ A hipótese residual de necessidade de duas pessoas idôneas permaneceu no parágrafo primeiro, que dispõe sobre o caso de ausência de perito oficial. Importante

\footnotetext{
${ }^{4}$ BADARÓ, Gustavo Henrique. Direito processual penal: tomo I. Rio de Janeiro: Elsevier, 2008. p. 226

${ }^{5}$ BADARÓ, Gustavo Henrique. Direito processual penal: tomo I. Rio de Janeiro: Elsevier, 2008. p. 226

${ }^{6}$ Art. 159. O exame de corpo de delito e outras perícias serão realizados por perito oficial, portador de diploma de curso superior. (Redação dada pela Lei no 11.690 , de 2008)

$1^{\circ} \mathrm{Na}$ falta de perito oficial, o exame será realizado por 2 (duas) pessoas idôneas, portadoras de diploma de curso superior preferencialmente na área específica, dentre as que tiverem habilitação técnica relacionada com a natureza do exame.
} 
ressaltar que tal disposição veio ao encontro de demanda existente em municípios menores, nos quais havia evidente dificuldade de se ter à disposição do Juízo dois peritos habilitados para cada caso. As mudanças introduzidas na disciplina do assistente técnico serão analisadas posteriormente, em tópico específico.

Ainda, a título de generalidades, cabe salientar que o exame pericial é indispensável no caso de crimes que deixam vestígios, conforme a expressa letra do artigo $158^{7}$ do Código processual penal pátrio. No entanto, no caso de desaparecimento desses vestígios, o próprio Código excepciona essa regra, admitindo o exame indireto, conforme o artigo $167 .^{8}$

Todavia, é importante frisar que, caso exista o corpo de delito, o exame pericial sobre este é requisito essencial à condenação. ${ }^{9}$ Contudo, o exame sobre o corpo de delito, ainda que conclusivo sobre as causas do crime, não pode levar imediatamente ao reconhecimento de sua autoria e demais nuances, eis que se resume à comprovação da materialidade. Outras informações relativas ao caso concreto merecem cuidadosa avaliação e interpretação, devendo ser valoradas junto aos demais elementos do conjunto probatório.

Por fim, como último ponto desse título, é essencial salientar a discussão existente sobre o mito da verdade científica, que há muito ronda o processo penal brasileiro, principalmente no que tange à prova pericial. Em que pese seja expresso no artigo $182^{10}$ do Código que o magistrado não se encontra adstrito ao laudo, podendo dele discordar, a ideia de que o conhecimento obtido de forma objetiva ostentaria certa superioridade sobre juízos de valor e interpretativos típicos de ciências humanas como a jurídica é, por óbvio, resquício do paradigma da racionalidade que fundou toda a construção do saber humano a contar do século XVII. O endeusamento da ciência é fortemente criticado por Aury Lopes Júnior, que utiliza para tanto o relativismo de Einstein e a máxima de que toda a forma de conhecimento científico nasce para ser, sempre e constantemente, superada. ${ }^{11}$ Assim,

\footnotetext{
${ }^{7}$ Art. 158. Quando a infração deixar vestígios, será indispensável o exame de corpo de delito, direto ou indireto, não podendo supri-lo a confissão do acusado.

${ }^{8}$ Art. 167. Não sendo possível o exame de corpo de delito, por haverem desaparecido os vestígios, a prova testemunhal poderá suprir-lhe a falta.

${ }^{9}$ Nesse ponto, importante salientar recente - e acertada - decisão proferida pelo Superior tribunal de Justiça no Habeas Corpus n. 350.996, que reconheceu a impossibilidade de condenação pelo delito de tráfico de drogas quando ausente o exame toxicológico.

${ }^{10}$ Art. 182. O juiz não ficará adstrito ao laudo, podendo aceitá-lo ou rejeitá-lo, no todo ou em parte.

${ }^{11}$ LOPES JR., Aury. Direito processual penal. São Paulo, Saraiva, 2015, 12a ed. p. 426
} 
nenhuma assertiva deveria ostentar o caráter de verdade universal e absoluta, ainda mais quando se está a tratar de um processo penal, o qual pode culminar no cerceamento de um dos direitos mais caros ao ser humano, qual seja, a liberdade.

\section{O PERITO E O ASSISTENTE TÉCNICO.}

O perito é o longa manus do juiz que o ajuda a compreender a prova, posto que dotado de conhecimentos técnicos, científicos ou artísticos. Na definição de José Frederico Marques, "o perito é órgão técnico e auxiliar do juízo na formação e colheita do material instrutório". 12

Nessa condição, o perito há de ser profissional que goza da confiança do juízo e que funcione nos autos sem nenhuma intervenção das partes, seja na condição de funcionário lotado em órgão da Polícia Judiciária, seja na condição de profissional nomeado.

A primeira disposição do Código trata dos peritos oficiais, investidos de função pública e, normalmente, lotados em órgãos da Polícia Científica. Estes tem o dever funcional de agir com imparcialidade e de empregar a maior extensão de capacidade técnica na execução do trabalho pericial. No que toca aos peritos nomeados, conquanto não investidos de função pública, devem aceitar o encargo e, neste caso, prestar compromisso de bem e fielmente desempenhar a função (art. 159, § $2^{\circ}$ ), o que evidentemente requer imparcialidade.

Peritos são, de todo modo, auxiliares da justiça e, nessa qualidade, devem conduzir seu trabalho de forma imparcial, independentemente da gravidade do crime ou da identidade ou qualidade das partes. Tanto é assim, que "as causas de suspeição são as mesmas dos juízes, como preceitua o art. 280 do Código de Processo Penal". ${ }^{13}$

Para Helio Tornaghi,

o perito não é funcionário nem serventuário da justiça, a menos que a lei crie cargo de perito no órgão judiciário do Estado (ou Distrito

\footnotetext{
${ }^{12}$ Elementos de direito processual penal. Edição revista e atualizada EDUARDO REALE FERRARI. Campinas, Millenium, $2^{\text {a }}$ ed., vol. II, p. 424.

${ }^{13}$ ARANHA, Adalberto José Q. T. de Camargo. Da prova no processo penal. São Paulo, Saraiva, 2004, $6^{\mathrm{a}}$ ed., p. 188.
} 
Revista Eletrônica de Direito Processual - REDP.

Rio de Janeiro. Ano 11. Volume 18. Número 3. Setembro a Dezembro de 2017

Periódico Quadrimestral da Pós-Graduação Stricto Sensu em Direito Processual da UERJ

Patrono: José Carlos Barbosa Moreira. ISSN 1982-7636. pp. 45-68

www.redp.uerj.br

Federal). Mas a perícia é serviço público (Statsdienst). O perito está sujeito à disciplina judiciária (Código de Processo Penal, art. 275) e a ele se aplicam os dispositivos das leis de organização judiciária relativos aos deveres e sanções, no que couber. Para os efeitos penais, é tido como funcionário público (Código Penal, art. 327). ${ }^{14}$

Além disso, de acordo com o artigo 156, $\S 5^{\circ}$, do CPC, o experto há de ser "comprovadamente detentor do conhecimento necessário à realização da perícia". Contudo, o artigo 159 do Código impõe que o perito deve somente ser "portador de diploma de curso superior". O $\S 1^{\circ}$ do artigo 159 ainda admite que, na falta de perito oficial, o exame seja realizado por duas pessoas idôneas, que devem ser portadoras de diploma de curso superior preferencialmente na área específica. ${ }^{15}$

Já os assistentes técnicos, ${ }^{16}$ como estabelece o artigo 466, $\S 1^{\circ}$, do Código de Processo Civil, são profissionais “de confiança da parte e não estão sujeitos a impedimento ou suspeição". Como sua indicação pelas partes pressupõe logicamente que eles sejam detentores de profundo conhecimento técnico, a lei não impõe nenhum tipo de comprovação dessa qualidade.

Mas o que distancia os assistentes dos peritos não é sua formação técnica, ${ }^{17}$ mas, fundamentalmente, a dispensa do dever de imparcialidade. Conquanto não seja de se imaginar que um profissional contrarie convicções científicas próprias para favorecer a parte que o contratou, ele não deixa de ser um auxiliar dessa mesma parte. Para Messina:

Os consultores técnicos são auxiliares do defensor. Por isso mesmo não têm de ser imparciais, mas, ao invés, hão de informar a defesa de tudo aquilo que lhe pode ser favorável e desprezar o que possa comprometer. Não podem mentir, mas não estão obrigados a dizer

\footnotetext{
${ }^{14}$ TORNAGHI, Hélio. Instituições de processo penal. Rio de Janeiro, Forense, 1959, vol. IV, p. 288.

15 Aqui notamos permissividade desarrazoada da lei processual. Conquanto a perícia não seja determinante no julgamento (como preceitua o art. 182 do Código de Processo Penal), devendo, sem hierarquia, ser valorada pelo juiz em conjunto com as demais provas do processo, não é de se ignorar sua importância.

${ }^{16}$ A lei 11.690, de 9 de junho de 2008, ao modificar o Código de Processo Penal, positivou na legislação processual penal a possibilidade de as partes indicarem assistentes técnicos (artigo $159, \S 3^{\circ}$ ), tal como já previa o Código de Processo Civil (artigo 464, § $1^{\circ}$, II).

${ }^{17}$ Esta, teoricamente, os deveria aproximar.
} 
toda a verdade, devendo omitir o que possa prejudicar o cliente.

Por isso mesmo não prestam juramento. ${ }^{18}$

De se ressaltar, neste ponto, que a dispensa do compromisso não autoriza o assistente técnico a mentir. Embora não seja o assistente técnico sujeito ativo passível de imputação pelo crime de falsa perícia, a inserção de elementos inexatos em parecer técnico com o fim de favorecer o réu pode configurar o crime de falsidade ideológica. ${ }^{19}$

No que toca ao contraditório, é fundamental destacar que os assistentes técnicos atuam posteriormente à elaboração do laudo pericial, conforme o artigo $159, \S 4^{\circ}$, do Código, por meio de pareceres técnicos, o que se depreende do artigo $159, \S 5^{\circ}$, inciso II. No entano, para isso, é necessário que haja perícia deferida. De acordo com o artigo 159, § $4^{\circ}$, do mesmo diploma, “o assistente técnico atuará a partir de sua admissão pelo juiz e após a conclusão dos exames e elaboração do laudo pelos peritos oficiais (...)”.

\section{AS INOVAÇÕES DA LEI N. 11.690/2008: BREVE PARALELO COM AS REGRAS DO CÓDIGO DE PROCESSO CIVIL.}

Embora boa parte da doutrina e da jurisprudência critique a incidência do princípio do contraditório na fase inquisitorial, já há relativo consenso, como se verá no título 4 infra, a respeito da necessidade de atuação defensiva anteriormente à ação penal.

No que toca especificamente ao princípio do contraditório - que, para limitar o campo de análise deste trabalho, ficará restrito ao procedimento judicial -, é forçoso reconhecer que a Lei n. 11.690/2008 trouxe significativas mudanças ao procedimento penal.

Talvez a mais importante delas é a que foi inscrita no artigo 155 do Código, que impede a condenação embasada exclusivamente na prova pré-processual, a respeito do que

\footnotetext{
${ }^{18}$ MESSINA. Il regime dele prove, p. 251 apud TORNAGHI, Hélio. Instituições de processo penal. Rio de Janeiro, Forense, 1959, vol. IV, p. 284.

${ }^{19}$. STJ, HC 42.727/DF, Rel. Min. Gilson Dipp, DJ 20.5.2005.
} 
importa esclarecer que o próprio dispositivo ressalva a possibilidade de utilização das provas "cautelares, não repetíveis e antecipadas". ${ }^{20}$

Especificamente no que toca à prova pericial, a Lei n. 11.690 de 2008 trouxe regramento que privilegia a celeridade, sem garantir com segurança a qualidade do exame pericial e a efetiva participação da defesa na produção da prova, mesmo que realizada em Juízo.

Na dicção anterior à lei, o artigo 159 do Código de Processo Penal dispunha que perícias deveriam ser feitas "por dois peritos oficiais", o que induziu, inclusive, a edição do verbete n. 361 do Supremo Tribunal Federal, segundo o qual “(...) é nulo o exame realizado por um só perito (...)".

Privilegiando a celeridade ou mesmo a falta de profissionais em áreas menos aparelhadas, o legislador resolveu permitir que a perícia fosse feita por um só perito, ressalvando a mera possibilidade de designação de mais de um experto no caso de "perícia complexa que abranja mais de uma área de conhecimento especializado", conforme artigo $159, \S 7^{\circ}$.

A novel redação do artigo 159 trouxe a exigência de que o perito seja portador de diploma de curso superior, ao passo que, anteriormente a 2008, essa qualidade era claramente cobrada apenas dos peritos estranhos aos órgãos oficiais, os quais eram nomeados pelo Juízo.

A alteração é evidentemente salutar, mas não é livre de críticas. São numerosos os casos de perícias feitas e subscritas por profissionais com formação em áreas inteiramente distintas das necessárias ao exame, o que representa enorme prejuízo ao desenvolvimento do processo, seja à acusação, seja à defesa. Afinal, sendo o perito pessoa dotada de conhecimentos técnicos, científicos ou artísticos, e se a lei exige que ele seja portador de diploma de curso superior, é de todo incoerente admitir que esse diploma advenha de área do conhecimento diverso da adequada à perícia.

Afinal, como adverte Michele Taruffo, "non existe soltanto la cattiva scienza; esistono anche i cattivi esperti, che sono anzi i magiori produttori di cattiva scienza". ${ }^{21}$

\footnotetext{
${ }^{20}$ São frequentes as hipóteses de perícias aparentemente não repetíveis em razão do desaparecimento ou do perecimento dos vestígios. Nesses casos, fica clara a necessidade de submissão da prova a contraditório diferido, com sua posterior valoração no julgamento.
} 
No processo civil, o Juízo não se socorre de órgãos oficiais. Além de ser a prova necessariamente produzida em Juízo, ${ }^{22}$ o perito nomeado, segundo a regra do artigo $156, \S$ $5^{\circ}$, do Código de Processo Civil, há de ser "comprovadamente detentor do conhecimento necessário à realização da perícia". Portanto, de acordo com a literalidade da norma processual civil, não basta a mera existência de diploma. É indispensável que o conhecimento comprovado pelo documento referido seja em área correspondente à necessária para a boa realização do exame.

Outro ponto fundamental é a inovadora figura do assistente técnico, já presente no processo civil, mas até então inaplicada na esfera processual penal. Entretanto, essa importação veio com modificações. De acordo com a redação atual do artigo 466, § $2^{\circ}$, do Código de Processo Civil, "o perito deve assegurar aos assistentes das partes o acesso e o acompanhamento das diligências e dos exames que realizar, com prévia comunicação, comprovada nos autos, com antecedência mínima de 5 (cinco) dias”.

Já a normativa processual penal, de acordo com o parágrafo quarto do artigo 159, determina que o assistente atue "após a conclusão dos exames e elaboração do laudo pelos peritos oficiais", o que, sem dúvida, diminui amplamente o espectro de atuação defensiva e torna a dialética processual mais burocrática que efetiva.

De toda sorte, a legislação privilegia o processo penal como instrumento de proteção do indivíduo contra o Estado ${ }^{23}$ ao positivar a possibilidade de oitiva dos peritos, inclusive com o encaminhamento de quesitos que poderão ser respondidos por meio de laudo complementar, conforme artigo $159, \S 5^{\circ}$, inciso I.

No processo civil, a regra é similar. Todavia, independentemente da existência de perícia, um experto pode ser ouvido em juízo, em caso que a legislação denomina "prova técnica simplificada" sobre "ponto controvertido da causa que demande especial conhecimento científico ou técnico", conforme o artigo 464, $\S 3^{\circ}$, coadunando-se com o regramento do processo penal da Itália.

\footnotetext{
${ }^{21}$ TARUFFO, Michele. Conoscenza scientifica e decisione giudiziaria: profili genereali, in Quaderni della Rivista Trimestrale di Diritto e Procedura Civile n. 8, p. 8/9.

${ }^{22}$ Pois até mesmo a prova cautelar é produzida judicialmente.

${ }^{23}$ TUCCI, Rogério Lauria. Teoria do direito processual penal: jurisdição, ação e processo penal (estudo sistemático). São Paulo, Revista dos Tribunais, 2002, p. 170.
} 
Revista Eletrônica de Direito Processual - REDP.

Rio de Janeiro. Ano 11. Volume 18. Número 3. Setembro a Dezembro de 2017

Periódico Quadrimestral da Pós-Graduação Stricto Sensu em Direito Processual da UERJ

Patrono: José Carlos Barbosa Moreira. ISSN 1982-7636. pp. 45-68

www.redp.uerj.br

\section{PERÍCIAS FEITAS NA FASE INQUISITORIAL E A ATUAÇÃO DEFENSIVA.}

A elevação da perícia como meio de prova ocorreu no processo penal italiano, a partir da evolução do processo penal romano, cujos meios identificados se limitavam à prova testemunhal, ao interrogatório do acusado e à reunião do material fruto do varejamento domiciliar. $^{24}$

A perícia é, sim, um meio de prova, mas não pode ser confundida com o resultado da prova. Segundo ensina Luis Fernando de Moraes Manzano, "o laudo pericial é um dos elementos de prova que o juiz valora para atingir o resultado da prova. Não tem valor definitivo, mas relativo. O juiz pode rechaçar a conclusão dos técnicos e, inclusive, ordenar a realização de nova perícia". ${ }^{25}$

Daí a necessidade de relativização do valor da perícia, que há de partir do pressuposto de que seres humanos são falíveis, inexistindo autoridade absoluta sobre aspectos do mundo fenomênico.

Há situações em que o trabalho pericial é trazido ao patamar de argumento de autoridade inquestionável, sendo, pois, necessárias ferramentas para tratar disso. ${ }^{26}$ Como pode o acusado, na evidente relação de hipossuficiência que mantém com o Estado-Juiz, se contrapor ao valor absolutista hodiernamente emprestados às perícias?

Há de se considerar que o avanço tecnológico fez da execução do crime algo muito mais sofisticado, pois o que outrora se fazia por meio de documento físico, faz-se digitalmente. Mesmo em território brasileiro, o agente criminoso pode ordenar operações de lavagem de dinheiro em qualquer lugar do planeta.

\footnotetext{
${ }^{24}$. FLORIAN, Eugenio. Delle prove penali. Milão, Casa Editrice Dottor Francesco Vallardi, 1924, vol. II, p. 324.

${ }^{25}$. MANZANO, Luís Fernando de Moraes. Prova pericial: admissibilidade e assunção da prova científica e técnica no processo brasileiro. São Paulo, Atlas, 2011, p. 6.

${ }^{26}$. Segundo a doutrina: "Entre nós, na linha dos ordenamentos continentais, também se pode afirmar haver grandes dificuldades para um exercício pleno do contraditório em relação à prova pericial: os peritos são, em regra, oficiais (art. $159 \mathrm{CPP}$ ) e, também como norma, as perícias são realizadas na fase do inquérito policial, em que ainda não existe a participação da defesa. Assim, embora se admita o contraditório posterior, nem sempre as informações técnico-científicas são elaboradas com vistas a uma discussão paritária entre os interessados, acabando por prevalecer uma versão única sobre os fatos examinados, aceita acriticamente, não só pelo juiz, como pelas próprias partes" - GOMES FILHO, Antonio Magalhães. Direito à prova no processo penal. São Paulo, Revista dos Tribunais, 1997, p. 156/157.
} 
Tal demanda gera a necessidade de que esse avanço tecnológico seja trazido também para os meios de prova. Afinal, é inviável que o Estado se contente com os meios tradicionais de investigação, sem modernizar seu comportamento.

Essa necessidade de modernização da prova está intimamente ligada ao crescimento da complexidade das questões levadas a julgamento, "cuja solução transcende a cultura comum ou do homem médio, que é o tipo de cultura não jurídica própria de um juiz ou jurado". ${ }^{27}$

Se, de um lado, é premente a necessidade de modernização do trabalho de apuração, também é fundamental garantir ao investigado acesso a esse avanço tecnológico para que consiga, em condições de igualdade, contrapor-se à acusação e aos elementos que a sustentam.

Isso ganha inegável relevância ao se considerar que, ao acusado, não é dado participar da produção da prova indiciária.

Embora a doutrina moderna defenda o exercício da defesa no inquérito policial, ${ }^{28}$ a praxis denota enorme distanciamento entre os investigados e a produção da prova que acaba por dar suporte ao início de uma ação penal e, quiçá, a uma condenação. Esse distanciamento é ainda maior se o sujeito dessa investigação não tem acesso a defesa privada.

E não é de se ignorar que, independentemente da identificação de um suspeito, a candência do fato criminoso demanda atuação rápida da Polícia técnico-científica. Minutos são preciosos quando os vestígios do crime podem perecer rapidamente.

Por outro lado, a não participação do acusado no exame pericial da fase inquisitorial não significa que o exame não possa ser refeito. De fato, segundo o que preceitua o artigo 159 , parágrafos $3^{\circ}$ a $7^{\circ}$, ambas as partes processuais têm papel ativo no exame pericial determinado em fase judicial.

Para tanto, contudo, há uma problemática a se enfrentar. No caso dos crimes cujos vestígios pereceram, o exercício do contraditório pode ser feito por meio de nova perícia? A resposta encontra apoio na diferença entre as perícias técnica e científica.

\footnotetext{
27. TARUFFO, Michele. A prova, traduzido por João GABRIEl CoUTO, São Paulo, Marcial Pons, 2014 , p. 87.

${ }^{28}$. SAAD, Marta. O direito de defesa no inquérito policial. São Paulo, Revista dos Tribunais, 2004.
} 
De fato, nova constatação de vestígios (perícia técnica), ${ }^{29}$ a priori, parece inexequível, já que os vestígios se perderam.

O mesmo, contudo, não se pode dizer do trabalho científico, que consiste no exame dos vestígios. ${ }^{30}$ Este pode ser questionado amplamente, afinal, "o progresso da ciência não garante uma pesquisa imune a erros e seus métodos, aceitos pela generalidade dos estudiosos em um determinado momento, podem parecer errôneos no momento seguinte". ${ }^{31}$ Isso sem considerar a falibilidade humana: ${ }^{32}$ a conclusão de determinado cientista pode e deve ser confrontada por exame posterior.

Negar perícia em juízo com supedâneo na mera existência de exame feito anteriormente à denúncia é, a nosso ver, admitir a aplicação de um princípio do contraditório pró-forma, sem efetividade nenhuma.

É certo que a Lei n. 11.690 de 2008 inseriu no Código de Processo Penal a possibilidade de inquirição dos peritos em juízo, inclusive com o encaminhamento de quesitos que podem vir a ser respondidos por meio de laudo complementar, conforme o artigo 159, $\S 5^{\circ}$, inciso I. A providência evidentemente fortalece a incidência do contraditório diferido, mas não resolve a questão.

Afinal, pode-se também admitir que se faça um exame científico, se a apuração préprocessual se restringiu a uma constatação. A título de exemplo, um exame contábil pode ter chegado a determinada conclusão que possibilitou o oferecimento de denúncia versando sobre crime financeiro; mas, na ação penal, a Defesa pode pleitear nova perícia com o intuito de comprovar que os métodos utilizados pelo perito são equivocados.

E com isso se toca numa questão bastante sensível: a possibilidade de vir o acusado a questionar a real expertise de um perito.

Apesar da disposição legislativa consubstanciar conquista bastante importante do direito de defesa, o pragmatismo mostra a resistência do Poder Judiciário em admitir a

\footnotetext{
${ }^{29}$. Aquela que "ilumina a prova”, cf. MANZANO, Luís Fernando de Moraes, Ob. cit., p. 15.

30. Idem.

31. MANZANO, Luís Fernando de Moraes. Ob. cit. p. 72.

32. Ao tratar do tema, o Prof. Antonio Magalhães Gomes Filho alerta: “(...) Como sublinhou Denti, o progresso da ciência não garante uma pesquisa imune a erros e seus métodos, aceitos pela generalidade dos estudiosos em um determinado momento, podem parecer errôneos no momento seguinte

Tal perigo é ainda maior quando se tem em conta que, nos ordenamentos de tipo continental, o perito é geralmente visto como um auxiliar do juiz, que exerce sua função com imparcialidade; o resultado disso é a tendência a se duvidar da própria inclusão da perícia entre os meios de prova e, o que é mais grave, de subtraí-la do controle do contraditório" - Ob. cit., p. 155/156.
} 
realização de perícias judiciais, especialmente porque, durante o inquérito policial, o exame de corpo de delito há de ter sido feito, sob pena de nulidade, conforme o artigo 564, III, $b$, do Código de processo penal. Nesses casos, e a partir da ressalva do artigo 184 do Código, ${ }^{33}$ a celeridade processual deixa de ser tratada como um direito individual para ser empregada como motivo para impedir medidas de defesa, assaz classificadas como

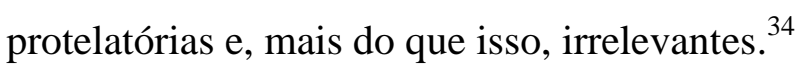

E, como ressalta Luis Fernando de Moraes Manzano, "o contraditório na prova é, sem dúvida alguma, melhor que o contraditório sobre a prova. Não poder intervir no procedimento técnico e não ter acesso à fonte de prova, para poder examiná-la e inferir a sua própria conclusão, compromete o contraditório. Por isso, o contraditório na prova, sempre que possível, deve ser assegurado".35

No que toca ao princípio do contraditório, a perícia produzida em juízo é uma das formas que o acusado tem de se contrapor à acusação. Trata-se de genuína forma de reação defensiva, expressão pura do princípio do contraditório, definido, segundo a lição de Antônio Scarance Fernandes, "por dois elementos: informação e reação". ${ }^{36}$

Recente alteração legislativa representou um sopro em favor da atuação defensiva no inquérito policial. A Lei n. 13.245 de 2016 acrescentou o inciso XXI ao art. $7^{\circ}$ da Lei 8.906 de 1994, estabelecendo serem "direitos do advogado": "assistir a seus clientes investigados durante a apuração de infrações, sob pena de nulidade absoluta do respectivo interrogatório ou depoimento e, subsequentemente, de todos os elementos investigatórios e probatórios dele decorrentes ou derivados, direta ou indiretamente, podendo, inclusive, no curso da respectiva apuração: a) apresentar razões e quesitos”.

A regra ainda depende de sedimentação jurisprudencial; mas, de todo modo, significa um avanço que pode vir a abranger o exame pericial.

Sem autorização de uma nova perícia na fase judicial, não há valor no direito de nomear assistente técnico. De acordo com o artigo 159, § 4, “o assistente técnico atuará a

\footnotetext{
33 Art. 184. "Salvo o caso de exame de corpo de delito, o juiz ou a autoridade policial negará a perícia requerida pelas partes, quando não for necessária ao esclarecimento da verdade".

${ }^{34}$ É o que se vê de decisão do Superior Tribunal de Justiça: HC 253.663/RS, Rel. Min. LAURITA VAZ, DJe 12.11.2014, p. 17 do voto condutor.

35. MANZANO, Luís Fernando de Moraes. Ob. cit. p. 75.

36. FERNANDES, Antonio Scarance. A reação defensiva à imputação. São Paulo, Revista dos Tribunais, 2002, p. 26/27.
} 
partir de sua admissão pelo juiz e após a conclusão dos exames e elaboração do laudo pelos peritos oficiais, sendo as partes intimadas desta decisão", o que leva a concluir que só há assistência se há perícia.

\section{PROBLEMAS NO EXERCÍCIO DO CONTRADITÓRIO DECORRENTES DA NOMEAÇÃO DE ASSISTENTE TÉCNICO.}

São muitos os problemas existentes no que tange à concretização da ampla defesa e do contraditório quando da realização da prova pericial no curso da ação penal. Em razão dos limites propostos nesse trabalho, se analisará especificamente as questões atinentes ao assistente técnico.

A primeira observação feita pela doutrina diz respeito ao fato da atuação do assistente técnico ocorrer de forma posterior à confecção do laudo pelo perito oficial, conforme se encontra expresso no parágrafo quarto do artigo $159 .{ }^{37}$ Ora, o prejuízo daí advindo é evidente, uma vez que o acompanhamento na realização do exame emprestaria ao assistente técnico, que também possui o conhecimento científico sobre o tema, a possibilidade de apresentar novas questões, bem como de criticar o próprio procedimento adotado na realização do exame. Nesse sentido apontamos Eugenio Pacelli:

"No ponto, a Lei $11.690 / 08$, embora portadora de grandes
inovações, sobretudo no que respeita à possibilidade de
participação do assistente técnico indicado pelas partes, não
resolveu o problema essencial. E isso porque a atuação da
defesa sobre o objeto periciado somente será possível após a
elaboração do laudo oficial e quando já em curso a ação
penal, isto é, depois da fase de investigação. Consulte-se, a
respeito, o disposto no art. 159 , parágrafos $4^{\circ}$ e $5^{\circ}$, CPP. Em
tais atuações, uma vez produzida a prova pericial, o
contraditório somente será realizado já perante a jurisdição, e
limitado ao exame acerca da idoneidade do(s) profissional(is)
responsável(is) pela perícia e das conclusões por ele(s)
alcançada(s), quando já perecido o material periciado. Nesse
campo, o objeto da prova, na maior parte das vezes, será a
qualidade técnica do laudo, e, particularmente, o

37 § 4o O assistente técnico atuará a partir de sua admissão pelo juiz e após a conclusão dos exames e elaboração do laudo pelos peritos oficiais, sendo as partes intimadas desta decisão. 
cumprimento das normas legais a ele pertinentes, por exemplo, a exigência de motivação, de coerência, de atualidade e idoneidade dos métodos, etc." 38

Assim, essencial para a garantia dos direitos das partes que o assistente técnico pudesse acompanhar toda a realização do exame pericial.

Conforme Aury Lopes Júnior, a concretização do contraditório e da ampla defesa em sede de ação penal só estaria perfectibilizada se fossem garantidas as seguintes atribuições às partes, no que tange à prova pericial: a) requerer sua produção; b) apresentar quesitos com antecedência mínima de 10 dias da realização da perícia; c) se possível, pela natureza do ato, acompanhar a colheita de elementos pelos peritos (extração de sangue, vestígios no local); d) manifestar-se sobre a prova, podendo requerer nova perícia, sua complementação ou esclarecimento dos peritos; e) indicar assistente técnico, que elaborará parecer sobre a perícia realizada; e) obter uma manifestação do juiz sobre a prova pericial realizada. ${ }^{39}$

Por fim, importante destacar que outro grave problema que não se subsome somente à questão da prova pericial diz respeito à disciplina das nulidades no processo penal. A importação de teorias afeitas ao processo civil gerou, de forma paulatina, a desconstrução de uma garantia ínsita ao processo penal, qual seja, a de que algumas formalidades, se desrespeitadas, deveriam acarretar a nulidade absoluta do procedimento.

No caso específico da prova pericial, em que pese o teor do artigo 564, III, alínea 'b', ${ }^{40}$ do Código de Processo Penal, o que se vislumbra na jurisprudência é o não reconhecimento da dita nulidade sem que, para tanto, seja necessária a prova do famigerado prejuízo, ente absolutamente evidente no caso se persecução penal. ${ }^{41}$ Assim,

\footnotetext{
${ }^{38}$ PACELLI, Eugenio. Curso de Processo penal. 16 ed. São Paulo: Atlas, 2012. p. 424

${ }^{39}$ LOPES JR., Aury. Direito processual penal. São Paulo, Saraiva, 2015, 12a ed. p. 430

${ }^{40}$ Art. 564. A nulidade ocorrerá nos seguintes casos:

III - por falta das fórmulas ou dos termos seguintes:

b) o exame do corpo de delito nos crimes que deixam vestígios, ressalvado o disposto no Art. 167;

41 "AGRAVO REGIMENTAL NO AGRAVO EM RECURSO ESPECIAL. PENAL E PROCESSUAL PENAL. ESTUPRO DE VULNERÁVEL. CONDENAÇÃO AMPARADA POR ELEMENTOS DE INFORMAÇÃO E PROVAS COLHIDAS DURANTE A INSTRUÇÃO CRIMINAL. CONTRADITÓRIO E AMPLA DEFESA PRESERVADOS. PRODUÇÃO PROBATÓRIA. INDEFERIMENTO. AUSÊNCIA DE PREJUÍZO. NULIDADE. INOCORRENTE. INTERROGATÓRIO. RÉU INTIMADO PESSOALMENTE. NÃO COMPARECIMENTO INJUSTIFICADO. NULIDADE. INOCORRENTE.

1. Não se pode conhecer de recurso especial fundado na alínea ' $c$ ' do permissivo constitucional quando a parte recorrente não realiza o necessário cotejo analítico entre os arestos confrontados, a fim de ficarem
} 
Revista Eletrônica de Direito Processual - REDP.

Rio de Janeiro. Ano 11. Volume 18. Número 3. Setembro a Dezembro de 2017

Periódico Quadrimestral da Pós-Graduação Stricto Sensu em Direito Processual da UERJ

Patrono: José Carlos Barbosa Moreira. ISSN 1982-7636. pp. 45-68

www.redp.uerj.br

mesmo em delitos considerados materiais, o indeferimento da realização de perícia e, consequentemente, da nomeação de assistente técnico, gera inegável dano à ampla defesa e ao contraditório, o que deveria, sem dúvida, acarretar a nulidade absoluta, jamais relativa, do processo penal.

\section{O PESO PROBATÓRIO DO LAUDO PARTICULAR.}

Por fim, no que tange à relação entre direito de defesa e prova pericial, essencial salientar algumas questões atinentes à oportunidade das partes de realizar, além da indicação de assistente técnico, a juntada de laudo pericial particular. Esta consiste em exame feito por profissionais que possuam conhecimento técnico na área, mas que não sejam peritos oficiais ou nomeados pelo juiz. A finalidade da perícia particular geralmente é a realização de contraprova ao laudo pericial.

Prevalece na doutrina e na jurisprudência que os pareceres técnicos oriundos de perícia particular serão juntados aos autos como prova documental. ${ }^{42} \mathrm{~A}$ princípio, tal assertiva não deveria acarretar qualquer dano quanto ao valor probatório, uma vez que não

demonstradas a similitude fática e a adoção de teses divergentes, sendo insuficiente a mera transcrição de ementa.

Divergência jurisprudencial não demonstrada.

2. No campo da nulidade no processo penal, vigora o princípio pas de nulité sans grief, segundo o qual, o reconhecimento de nulidade exige a comprovação de efetivo prejuízo (art. 563 do Código de Processo Penal). Foi, desse modo, editado pelo Supremo Tribunal Federal o enunciado sumular 523, que assim dispõe: No processo penal, a falta de defesa constitui nulidade absoluta, mas a sua deficiência só o anulará se houver prova de prejuízo para o réu.

3. Nessa linha, a demonstração do prejuízo sofrido pela defesa que, em alguns casos de nulidade absoluta, por ser evidente, pode decorrer de simples raciocínio lógico do julgador, é reconhecida pela jurisprudência atual como imprescindível tanto para a nulidade relativa quanto para a absoluta, consoante retratam julgados do Supremo Tribunal Federal e do Superior Tribunal de Justiça.

4. No caso, quanto ao indeferimento do pedido de realização de prova pericial e de nomeação de assistente técnico, o recorrente, a despeito de arguir nulidades, não expôs qual o prejuízo suportado em seu direito de defesa.(...)

7. Agravo regimental não provido. (AgRg no AREsp 807.827/SP, Rel. Ministro REYNALDO SOARES DA FONSECA, QUINTA TURMA, julgado em 10/03/2016, DJe 16/03/2016)

${ }^{42}$ CORREIÇÃ O PARCIAL. JÚRI. PERÍCIA PARTICULAR. VALOR RELATIVO. CERCEAMENTO DE DEFESA. 1- Tratando-se de homicídio doloso o julgamento do mérito não é de competência do juiz singular, portanto, os critérios para indeferir a juntada de peças produzidas pela defesa é tão só quando tais elementos são desnecessários ou provas ilícitas. 2- 'Perícia ¿ particular não é prova ilícita. Tem o valor de documento particular e será aferido juntamente com os demais elementos recolhidos aos autos. O indeferimento pode configurar cerceamento de defesa se a peça foi produzida como elemento da tese defensiva. PROVIDO. (Correição Parcial No 70030357149, Terceira Câmara Criminal, Tribunal de Justiça do RS, Relator: Elba Aparecida Nicolli Bastos, Julgado em 10/09/2009)". 
subsiste no Brasil o sistema de provas tarifadas, o qual é considerado pela doutrina como tipicamente inquisitório. A questão que se deve destacar aqui é a já aventada no primeiro tópico desse trabalho, quando se abordou que a ideia de prevalência da verdade científica ainda persiste na ciência jurídica brasileira, sobremaneira no pertinente aos procedimentos probatórios em matéria processual penal. Esse pensamento pode acarretar que se erija o exame pericial a um patamar de incontestabilidade, o que causa sérios danos à concretização do direito de defesa.

Importante destacar ainda que, caso a perícia particular contrarie a perícia oficial, o magistrado poderá determinar a realização de uma terceira perícia.

A perícia particular é de difícil realização na fase de inquérito, mesmo já se tendo consolidado a existência de direito de defesa, ainda que mitigado, nessa fase procedimental, o que se deu principalmente após a edição da Súmula vinculante n. $14^{43} \mathrm{e}$ as recentes alterações feitas na Lei n. 9.806 de $1994 .{ }^{44}$ Tal fato, destacado por Aury Lopes Júnior, ${ }^{45}$ prejudica sobremaneira o acusado, uma vez que, como já salientado, grande parte das provas periciais se dão anteriormente ao início da ação penal, principalmente em razão da conservação do local do crime e mesmo do perecimento do objeto a ser periciado.

Como último ponto, deve-se destacar que a perícia particular acaba por ser um meio defensivo que depende, sobretudo, da condição financeira do acusado, uma vez que o renome do perito contratado influencia na confiabilidade do seu laudo e, por consequência, na formação do convencimento sobre a prova produzida.

\section{LEGISLAÇÃo COMPARADA: PERÍCIA E ASSISTENTE TÉCNICO NO CHILE E NA ITÁLIA.}

Por fim, encerrada a análise do direito brasileiro, e atendo-se aos limites desta pesquisa, é proposta uma breve incursão na legislação comparada de dois países que muito

\footnotetext{
${ }^{43}$ É direito do defensor, no interesse do representado, ter acesso amplo aos elementos de prova que, já documentados em procedimento investigatório realizado por órgão com competência de polícia judiciária, digam respeito ao exercício do direito de defesa.

${ }^{44}$ Art. $7^{\circ}$ São direitos do advogado: XIV - examinar, em qualquer instituição responsável por conduzir investigação, mesmo sem procuração, autos de flagrante e de investigações de qualquer natureza, findos ou em andamento, ainda que conclusos à autoridade, podendo copiar peças e tomar apontamentos, em meio físico ou digital;

${ }^{45}$ LOPES JR., Aury. Direito processual penal. São Paulo, Saraiva, 2015, 12a ed. p. 430
} 
Revista Eletrônica de Direito Processual - REDP.

Rio de Janeiro. Ano 11. Volume 18. Número 3. Setembro a Dezembro de 2017

Periódico Quadrimestral da Pós-Graduação Stricto Sensu em Direito Processual da UERJ

Patrono: José Carlos Barbosa Moreira. ISSN 1982-7636. pp. 45-68

www.redp.uerj.br

influenciaram o processo penal pátrio, quais sejam, Chile e Itália. A observação feita nesse ponto será restrita à prova pericial e à participação de assistente técnico nas legislações analisadas.

No processo penal chileno, a disciplina da prova pericial se encontra nos artigos 314 a 322 do Código de Processo Penal. A principal diferença a ser observada em relação ao direito brasileiro é que, no caso chileno, toda a produção da prova pericial é voltada à atuação das partes ${ }^{46}$, não sendo o perito considerado um auxiliar do juízo, como no Brasil. Tal fato, conforme crítica já feita por Aury Lopes Júnior, tem especial relevância quanto à preservação do caráter acusatório do sistema. ${ }^{47}$ Nesse sentido, desnecessária se faz a figura do assistente técnico, uma vez que o próprio perito tem sua atuação dirigida à defesa e à acusação.

Importante salientar que a remuneração do perito pelas partes pode ser mitigada pelo juízo quando o réu não apresentar condições financeiras de fazê-lo e a prova for considerada essencial para o deslinde do fato, visando à manutenção do contraditório, da paridade de armas e da mais ampla defesa. ${ }^{48}$

Ademais, subsiste no Chile a figura do juiz das garantias, ${ }^{49}$ o qual atua durante a investigação, não tendo competência para julgar o feito, ante sua evidente contaminação

\footnotetext{
${ }^{46}$ Artículo 314. - Procedencia del informe de peritos.

El ministerio público y los demás intervinientes podrán presentar informes elaborados por peritos de su confianzay solicitar en la audiencia de preparación del juicio oral que éstos fueren citados a declarar a dicho juicio, acompañando los comprobantes que acreditaren la idoneidad profesional del perito. Procederá el informe de peritos en los casos determinados por la ley y siempre que para apreciar algún hecho o circunstancia relevante para la causa fueren necesarios o convenientes conocimientos especiales de una ciencia, arte u oficio. Los informes deberán emitirse con imparcialidad, ateniéndose a los principios de la ciencia o reglas del arte $u$ oficio que profesare el perito.

${ }^{47}$ LOPES JR., Aury. Direito processual penal. São Paulo, Saraiva, 2015, 12a ed. p. 425

${ }^{48}$ Artículo 316.- Admisibilidad del informe y remuneración de los peritos. El juez de garantía admitirá los informes y citará a los peritos cuando, además de los requisitos generales para la admisibilidad de las solicitudes de prueba, considerare que los peritos y sus informes otorgan suficientes garantías de seriedad y profesionalismo. Con todo, el juez de garantía podrá limitar el número de informes o de peritos, cuando unos $u$ otros resultaren excesivos o udieren entorpecer la realización del juicio. Los honorarios y demás gastos derivados de la intervención de los peritos mencionados en este artículo corresponderán a la parte que los presentare. Excepcionalmente, el juez de garantía podrá relevar a la parte, total o parcialmente, del pago de la remuneración del perito, cuando considerare que ella no cuenta con medios suficientes para solventarlo o cuando, tratándose del imputado, la no realización de la diligencia pudiere importar un notorio desequilibrio en sus posibilidades de defensa. En este último caso, el juez de garantía regulará prudencialmente la remuneración del perito, teniendo presente los honorarios habituales en la plaza y el total o la parte de la remuneración que no fuere asumida por el solicitante será de cargo fiscal.

${ }^{49}$ Importante destacar que o juiz das garantias seria uma das inovações propostas no PL n. 156, que prevê a criação de um novo Código de Processo Penal.
} 
pelo contato demasiado com a produção probatória. É esse o magistrado que zela pela regularidade durante o procedimento probatório pericial. ${ }^{50}$

No que toca ao sistema italiano, destacamos que, tal como no processo penal brasileiro, alhures se prevê que os peritos estão sujeitos às mesmas regras de suspeição e impedimento dos magistrados. Entretanto, o art. 223, 2, do Código de Processo Penal daquele país regulamenta expressamente a recusa da parte com base nessas regras e estabelece mecanismo mais claro para expressá-la: uma declaração de recusa apresentada até que seja efetivada a formalidade do juramento de bem desempenhar a função. Embora no Brasil não seja a parte impedida dessa manifestação, não há um mecanismo claro.

A regra, por lá, é que a formalidade de investidura na função ocorra em audiência, oportunidade em que o juiz já formula quesitos (art. 226, 2) e, a depender da complexidade, o perito já os responde imediatamente (art. 227, 2). É o mesmo que admite o Código de Processo Penal brasileiro (art. 159, § 5 , I), mas aqui se condiciona ao chamamento de perito que já tenha, sobre o fato do processo, produzido laudo.

$\mathrm{Na}$ Itália o assistente técnico pode ser indicação inclusive dos acusados que não possuam condições financeiras para arcar com os custos da contratação. Nesse caso, o Estado fica encarregado do pagamento dos honorários (art. 225, 2). ${ }^{51}$

Os assistentes técnicos - que na Itália são indicados por Acusação e Defesa podem participar da perícia, propondo diligências diretamente ao perito, formulando observações e ressalvas (art. 230,2). E, se nomeados depois da perícia, podem examinar o laudo e requerer ao juiz autorização para exame da pessoa, coisa e lugar objeto de perícia $(\operatorname{art} .230,3){ }^{52}$

\footnotetext{
${ }^{50}$ Artículo 320.- Instrucciones necesarias para el trabajo de los peritos. Durante la etapa de investigación o en la audiencia de preparación del juicio oral, los intervinientes podrán solicitar del juez de garantía que dicte las instrucciones necesarias para que sus peritos puedan acceder a examinar los objetos, documentos o lugares a que se refiriere su pericia o para cualquier otro fin pertinente. El juez de garantía accederá a la solicitud, a menos que, presentada durante la etapa de investigación, considerare necesario postergarla para proteger el éxito de ésta.

51. "Art. 225 (Nomina del consulente tecnico) - 1. Disposta la perizia, il pubblico ministero e le parti private hanno facoltà di nominare propri consulenti tecnici in numero non superiore, per ciascuna parte, a quello dei periti.

2. Le parti private, nei casi e alle condizioni previste dalla legge sul patrocinio statale dei non abbienti, hanno diritto di farsi assistere da un consulente tecnico a spese dello Stato".

52. "Art. 230 (Attività dei consulenti tecnici) - 1. I consulenti tecnici possono assistere al conferimento dell'incarico al perito e presentare al giudice richieste, osservazioni e riserve, delle quali è fatta menzione nel verbale.
} 
Se o perito não apresenta o trabalho pericial no prazo fixado pelo Juízo, pode ser substituído. Nesse caso é chamado a explicar-se em Juízo e, a depender do caso, pode ser condenado ao pagamento de multa (art. 231, caput e 3).

O Código de Processo Penal Italiano admite a nomeação de assistentes técnicos mesmo quando não há perícia e permite a eles que exponham diretamente ao juiz suas conclusões por meio de memoriais (art. 233, 1), ${ }^{53}$ que hão de ser apreciados (art. 121). Aplicada essa regra à realidade brasileira, representaria um valioso caminho no questionamento da prova produzida durante a fase investigativa.

\section{CONSIDERAÇÕES FINAIS.}

É inegável a importância da perícia como meio de prova. Da análise do vestígio do crime muito se pode extrair e a muitas conclusões se pode chegar.

A figura do assistente técnico, ainda que com atuação posterior à perícia, representa, sem dúvida, uma considerável evolução na participação do acusado na produção da prova, bem como o fortalecimento da índole do processo penal enquanto instrumento de proteção do indivíduo.

Talvez o mais grave dos problemas das perícias no processo penal brasileiro esteja no descompasso entre a previsão legislativa e a realidade prática. Isso sem que a lei tenha previsto mecanismos de proteção contra o que Taruffo chama de "cattivi esperti". ${ }^{54} \mathrm{Sim}$, os maus peritos, despreparados para o exame que diariamente exercem.

Eis, pois, a necessidade da presença do assistente técnico, ainda que com atuação, com dissemos, a posteriori. Mesmo sem participar diretamente dos exames, e sem o

2. Essi possono partecipare alle operazioni peritali, proponendo al perito specifiche indagini e formulando osservazioni e riserve, delle quali deve darsi atto nella relazione.

3. Se sono nominati dopo l'esaurimento delle operazioni peritali, i consulenti tecnici possono esaminare le relazioni e richiedere al giudice di essere autorizzati a esaminare la persona, la cosa e il luogo oggetto della perizia.

4. La nomina dei consulenti tecnici e lo svolgimento della loro attività non può ritardare l'esecuzione della perizia e il compimento delle altre attività processuali".

53. “Art. 233 (Consulenza tecnica fuori dei casi di perizia) - 1. Quando non è stata disposta perizia, ciascuna parte può nominare, in numero non superiore a due, propri consulenti tecnici. Questi possono esporre al giudice il proprio parere, anche presentando memorie a norma dell 'art. 121'.

54 . TARUFFO, Michele. Ob. cit. 
contato direto com o perito, os assistentes podem questionar a metodologia de análise, bem como os critérios científicos que levaram às conclusões dispostas no laudo.

Destacamos, ainda, que a interpretação da lei processual há de ser consentânea com o espírito dos diplomas internacionais de proteção aos direitos humanos e, antes disso, com a Constituição Federal, que protege como garantias individuais os princípios da ampla defesa e do contraditório.

Entretanto, a prática da justiça penal brasileira tem mostrado excessivas restrições ao direito à prova, especialmente no que toca à perícia: são reiterados os indeferimentos de pedidos de exames periciais com base em uma necessidade de conferir andamento célere à ação penal, em interpretação claramente equivocada do direito constitucional à duração razoável do processo.

O exercício do contraditório em relação à perícia produzida na fase inquisitorial da persecutio criminis há de consistir em muito mais do que a mera reinquirição de testemunhas em juízo. Sendo ao acusado, em regra, impossível participar de diligências empreendidas no inquérito policial, é essencial que este tenha garantida a disponibilidade do aparelho Estatal para novo exame, se viável.

\section{REFERÊNCIAS BIBLIOGRÁFICAS:}

ANDRADE, Rodrigo Fernando Barbosa de; BEZERRA, José Wellton de Sousa. A perícia oficial no processo penal. Impressões, Brasília, v. 2, n. 5, p. 34-35, jan. 2000

ARANHA, Adalberto José Q. T. de Camargo. Da prova no processo penal. São Paulo, Saraiva, 2004, $6^{\mathrm{a}}$ ed.

BADARÓ, Gustavo Henrique. Direito processual penal: tomo I. Rio de Janeiro: Elsevier, 2008.

FERNANDES, Antonio Scarance; ALMEIDA, José Raul Gavião de (Coord.). Provas no processo penal: estudo comparado. São Paulo: Saraiva, 2011

GOMES FILHO, Antonio Magalhães. Direito à prova no processo penal. São Paulo, Revista dos Tribunais, 1997.

LOPES JR., Aury. Direito processual penal. São Paulo, Saraiva, 2015, $12^{\text {a }}$ ed. 
MANZANO, Luís Fernando de Moraes. Prova pericial: admissibilidade e assunção da prova científica e técnica no processo brasileiro. São Paulo, Atlas, 2011.

MARINONI, Luiz Guilherme. ARENHART, Sérgio Cruz. Prova. São Paulo, Revista dos Tribunais, $2^{\mathrm{a}}$ ed. 2011.

MARQUES, José Frederico. Elementos de direito processual penal. Edição revista e atualizada EduARdo ReAle FerRari. Campinas, Millenium, $2^{\mathrm{a}}$ ed.

SAAD, Marta. O direito de defesa no inquérito policial. São Paulo, Revista dos Tribunais, 2004.

SILVA, Alexandre Alberto Gonçalves da; SANCHEZ, Pedro Luís Próspero. A perícia como garantidora dos Direitos Humanos no século XIX. Revista da Faculdade de Direito de São Bernardo do Campo, São Bernardo do Campo, v. 14, n. 16, p. 1-14, anual. 2010

PACELLI, Eugenio. Curso de Processo penal. 16 ed. São Paulo: Atlas, 2012.

PITOMBO, Cleunice Valentim Bastos. Considerações iniciais sobre a lei 11.690/08. In: Boletim IBCCRIM, n. 188. Julho, 2008.

PRADO, Geraldo. Sistema acusatório: a conformidade constitucional das leis processuais penais. 4. ed. Rio de Janeiro: Lumen Juris, 2006.

SOARES, Luiz Eduardo; GUINDANI, Miriam Krenzinger A. A construção social de uma acusação criminal: desconstruindo o uso de provas periciais. Revista de Estudos Criminais, Porto Alegre, v. 5, n. 19, p. 39-52, jul./set. 2005

TARUFFO, Michele. Conoscenza scientifica e decisione giudiziaria: profili genereali, in Quaderni della Rivista Trimestrale di Diritto e Procedura Civile n. 8 A prova, traduzido por Jỗo GABRIEL CoUTO, São Paulo, Marcial Pons, 2014.

THEODORO JÚNIOR, Humberto. Admissibilidade da prova pericial complexa. Direito à prova e garantias processuais constitucionais. Revista da ABPI, Rio de Janeiro, n. 89, p. 63-71, jul./ago. 2007

TORNAGHI, Hélio. Instituições de processo penal. Rio de Janeiro, Forense, 1959.

TUCCI, Rogério Lauria. Teoria do direito processual penal: jurisdição, ação e processo penal (estudo sistemático). São Paulo, Revista dos Tribunais, 2002 
Rio de Janeiro. Ano 11. Volume 18. Número 3. Setembro a Dezembro de 2017

Periódico Quadrimestral da Pós-Graduação Stricto Sensu em Direito Processual da UERJ Patrono: José Carlos Barbosa Moreira. ISSN 1982-7636. pp. 45-68

VAZ, Denise Provasi; GALVÃO, Danyelle da Silva. Da atuação do assistente técnico no processo penal brasileiro. Revista Brasileira de Ciências Criminais, São Paulo, v. 19, n. 90, p. 211-243, mai./jun. 2011.

VILARES, Fernanda Regina; LOPES, Mariangela. Manifestação do assistente técnico e a reforma do código de processo penal: meio de prova atípico; procedimento. Boletim IBCCRIM, São Paulo, n. 194, jan. 2009. 